\title{
SAFE CITY PROGRAMME: ARE WE ON THE RIGHT PATH TO REDUCE CRIME? ${ }^{1}$
}

\author{
Kamalruddin bin Shamsudin ${ }^{2}$ \\ Federal Department of Town and Country Planning (FDTCP), Peninsular Malaysia \\ MINISTRY OF HOUSING AND LOCAL GOVERNMENT
}

\begin{abstract}
Generally all types of property crime showed increase in occurrences; snatch theft showed a positive decline from 2004 to 2006 and stabilized in 2007. The safe city programme originated with the aim of putting across measures or steps that local authorities (PBTs) could implement immediately to reduce crime occurrences. Effectiveness of CCTV showed mixed result. Lessons from accredited safe city elsewhere (in particular Melbourne) suggest possible future directions for the safe city programme in Malaysia.
\end{abstract}

Keywords: Safe city, property crime, media, CCTV, crime severity classification, snatch theft, crime mapping, evidence-based planning, CPTED

\section{INTRODUCTION}

This article gives an overview of the safe city programme under the purview of the Ministry of Housing and Local Government (MHLG). Extent of local authorities involvement and their contribution to crime reduction (or otherwise) are discussed. More importantly are these efforts contributing to a safer city. In this regard I would like to share some ideas based on my involvement overseeing the programme and a recent visit to Melbourne (rated the most safest city in the southern hemisphere by WHO in 2000 and most livable city in the world in 2003 and 2004 by Economist Intelligent Unit) and to Adelaide. Readers of course will want to know how this programme will affect them, be they planners, architects, developers, local authorities' officers, the police and various segment of the public.

\footnotetext{
'This is a revised version of a paper presented at the World Habitat Day, Kuala Lumpur $\left(22^{\text {nd }}\right.$ November 2007$)$ organised by MHLG, EAROPH and UN-HABITAT

2 Deputy Director General 1, Federal Department of Town and Country Planning (FDTCP), Peninsular Malaysia (kamalruddin@townplan.gov.my)
} 


\section{SOME RECENT MEDIA SPLASH}

If you have missed on some happenings in the media lately, the New Straits Times (dated $9^{\text {th }}$ January 2008) headlined "Crime Rate Up 13.4\%". It further recalled that the cabinet in 2004 had decided for more CCTVs to be installed at public buildings and public places; and that the MHLG assigned to the task appeared to have run into problems. The latter statement no doubt puts the ministry in a spot. Further the Prime Minister said that from now onwards the police will decide where CCTV to be installed (their coverage) and commercial buildings and complexes will be required to install the CCTV at their own cost; failing which appropriate action will be taken by the police against noncompliance. [probably revoking their licence]

After the cabinet meeting a day later, the MHLG's Minister, Y.B. Dato' Seri Ong $\mathrm{Ka}$ Ting said that the Cabinet had in the morning instructed his ministry to direct all local authorities to install CCTV based on the locations provided by the police. [nothing about that statement that the task appeared to have run into problems].Prior to this announcement, the Ministry, in early December 2007, had secured approval from Cabinet an allocation of about RM75 million for the remaining three years in the Ninth Malaysia Plan (2008, 2009 and 2010) based on a paper prepared by the FDTCP, but only after the visit by the Prime Minister to Bukit Aman, and the said cabinet meeting, was this amount mentioned to the media. In fact, according to the safe city programme (MHLG, 2004) CCTV must be installed with the police and public involvement and feedback. I most certainly hope we don't forget the public involvement and that the local authority does not interpret the Prime Minister's directive in a robotic manner. Directives from the National Council for Local Government have spelled this out in 2007 - to include the public involvement as well.

The ensuing days saw The STAR newspaper ${ }^{4}$ giving extensive coverage on safe city issues and CCTV, and I was quoted extensively based on a paper presented at a recent seminar in Kuala Lumpur ${ }^{5}$. I will clarify certain points where necessary.

Someone from a government agency called me up recently, to ask whether we could allow $5.4 \mathrm{MHz}$ bandwidth for CCTV installation. He was responding to a

3 The spike in crime statistics was partly attributed to the inclusion of five new categories i.e. criminal intimidation, outraging modesty, causing hurt, extortion and rioting. NST page $2,9^{\text {th }}$ January 2008 .

${ }^{4}$ INSIGHT, STARMAG, SUNDAY 13 JANUARY 2008

5 World Habitat Day, Kuala Lumpur $\left(22^{\text {nd }}\right.$ November 2007$)$ organised by MHLG, EAROPH and UN-HABITAT. 
query by a private firm, reportedly engaged by the State government or local authority, to install CCTV in the State. I responded that they have to comply with the CCTV guideline already endorsed by the National Council for Local Council which amongst others had made recommendations on the international specification of the public safety system bandwidth of $4.9 \mathrm{GHz}$ for uninterrupted usage and stability of video recording and image quality, and a number of other technical specification required by the police etc. It is feared that the State's good intention of installing many CCTVs may be going ahead without proper advise from the MHLG -and we will face the same issue of CCTVs not performing as it should because of non-compliance, and this time on a larger scale and substantially greater cost to be involved to make right.

\section{BACKGROUND TO THE SAFE CITY PROGRAM AND HOW THE MEASURES WERE DEVELOPED}

Crime occurrences received wide coverage in the media in 2003 and early 2004 , in particular where the victims were traumatized or where death occurred. The MHLG was directed by Cabinet to look into this - thereafter establishing the safe city program in August $2004^{6}$.

A couple of preliminary conceptual papers were discussed at the Ministry level and these didn't reflect closely what the Ministry had in mind. These early drafts were largely planning- focused and not tailored to immediate actions that the local authorities could implement. They were abstract ideas needing translation, too large a coverage on various safety issues - physical, social and crime related etc. The secretary general asked "How may crime occurrences can be reduced through local authority action?" - that was the object of the exercise. [and I should add any evaluation of this programme must keep this in mind by not incorporating a wider generic safe city evaluation framework which the Ministry never had in mind in the first place]

${ }^{6}$ Readers can go through all the 23 measures from the safe city programme at www.townplan.gov.my. Illustration of the 23 measures can be downloaded (English and the National Language version is available). 
Going back to the 'drawing board', planners came out with 23 steps for crime prevention and so it was. These 23 steps or measures were not generated from thin air. Planners, despite having wide exposure in planning duties, went to the ground, met various stakeholders (police, NGOs, resident associations, criminologist and the Malaysian Crime Prevention Foundation), visited crime locations; and in the process got chided as well (the police think about crime 24 hours, planners how much?) and many more useful tips (indeed planners were traversing a 'closely guarded' territory to some and a turf encroachment to others). But planners persisted because we have moved beyond a 'blue print model, multi-disciplinary model, and 'inter-disciplinary model' to 'a transdisciplinary model ${ }^{8}$. In short, planners went beyond their turf, and moved into the heart of the matter (could be read 'hard' matter) and exchanged notes emanating from the weaknesses in the 'system' of the government machinery where crime prevention was concerned. The exercise was inductive, consultative and a learning process. But it was not exhaustive given the fast track nature of the exercise. Thus, by August 2004, the MHLG's Minister briefed the Cabinet on the 23 steps of crime prevention to be implemented by 38 municipalities and cities in Peninsular Malaysia?

The initial focus on crime also required clarification, as it was unlikely that the Ministry would handle various crime dimensions. Planners at the FDTCP narrowed the scope to property crime i.e. 1) burglary (commonly known as house break-ins); 2) car theft; 3) motorcycle theft; 4) van, lorry, and heavy machinery theft; 5) snatch theft; and 6) other thefts. Of the six, the last one (other thefts, especially within office building and buses, have not been given attention). Also, the program steered away from serious crimes (a police domain). Although, from property crimes, serious crimes may arise, for example rape cases and murders arising from car thefts (where the victim is also involved) or death resulting from snatch theft.

${ }^{7}$ When the concept and safe city measures were developed, the ministry had earlier received endorsement from the National Council for Local Government on its proposed "Measures To Improve Local Authority Delivery Service". In it were 64 steps (64 langkah-langkah) required of local authority to improve their services to the public. The safe city program drafted by the FDTCP was directed to have a similar format, thus the wording of 'steps' or 'measures' had been used. There was no lengthy explanation only basic clarification of measures or action required of local authorities.

${ }^{8}$ Trans-disciplinary model can be generally to mean crossing disciplinary and cultural boundaries requiring sound knowledge of one's own discipline (especially its limitations), open-mindedness, great patience, and sincere effort on all sides.

9 Cities in Sarawak and Sabah despite not under the purview of MHLG were also interested in the programme and received briefing on the programme. 


\section{HOW WERE THE MEASURES DERIVED?}

The measures incorporated were derived from various local and international sources. From the Malaysian Crime Prevention Foundation ${ }^{10}$ (MCPF) and resident -associated measures, like the importance of lighting-up backlanes and five foot ways, the need to separate pedestrian from motor vehicular lanes, education on crime prevention and organized resident involvement, and the use of CCTV etc; from the police the experience of CCTV usage and operation, site requirement for the police bit, crime prevention education; from criminologists, the concern of public surveillance and target hardening; from local authorities, their experience of motorcycle locking devices etc; from planners, urban designers and architects - Crime Prevention Through Environmental Design (CPTED); from Sydney, the emergency button and from Adelaide, the safety mirrors and various CPTED concepts (for example settingup small business activities along potential high risk pedestrian routes to provide an eye or natural surveillance on the area). The Deputy Minister MHLG (Y.B. Dato' Robert Lau) too came out with ideas of making sure public places and private property were well-kept, and that public places and parks had proper maintenance and security services. Visits to various crime sites, talking with various stakeholders concerned over public safety and their experience and success level (and failures), and provided additional treatment over the measures in regards to how it could be done according to local authority's requirements.

It is worth stressing that an over-riding aim was that these measures must be easily implemented by the local authority; thus except for CCTV (which only a few PBT could install), services of security personals and certain planning guidelines, most of the measures can be implemented with minimal cost or already were part of the function of local authorities (I repeat, part of the local authority function). To make it easier for local authorities to implement these steps, an illustrative booklet on crime prevention was published by FDTCP and distributed to all local authorities and stakeholders. To-date more than 10,000 copies have been distributed.

\section{TEACH-IN AND SEMINARS}

Numerous teach-ins and workshops were conducted involving the police, PBT staff; international expert in CPTED (from Australia) and seminars were

${ }^{10} \mathrm{MCPF}$ had earlier initiated the safe city initiatives in 1997 with Bangsar as one of their early experience. This was followed by other programmes. 
conducted at various locations in the country ${ }^{11}$. Consequently the safe city booklet was amended a number of times basing on new experience (within a two year period) and recently a booklet on the revised specifications for CCTV was published based on a joint committee of the MHLG and the Royal Malaysian Police with input from various ministries, local authorities and CCTV experts. ${ }^{12}$

\section{IMPLEMENTATION STATUS 2004-2007}

Since its inception in 2004, a total of 5 reporting periods were made by the secretariat. ${ }^{13}$ The following summarised the implementation status by 38 local authorities in Peninsular Malaysia. ${ }^{14}$

Table 1: Progress of Implementation by PBT (2005-2007)

\begin{tabular}{lc}
\hline Period & More than $50 \%$ measures implemented: \\
\hline January - December 2005 & 18 PBT with average $50 \%$ \\
January - March 2006 & 33 PBT with average $67 \%$ \\
April - August 2006 & 35 PBT with average $70 \%$ \\
September - December 2006 & 37 PBT with average $73 \%$ \\
January - April 2007 & 38 PBT with average $78 \%$ \\
\hline
\end{tabular}

Source: Based on various PBT reporting to the secretariat between Jamuary 2005-April 2007

The 50\% minimum implementation target was set by the Minister of MHLG. Thus, it could be seen that PBTs began achieving $70 \%$ status in the first quarter of 2006, almost one and half years later. [this so-called progress however has come under scrutiny, as many if not all PBTs only covered a small segment of crime related areas]

${ }^{11}$ CPTED guidelines are currently been research into by the Federal Town and Country Planning department. Allocation is provided for in the $9^{\text {th }}$ Malaysia Plan. The guideline would assist PBTs in ensuring various CPTED principles are incorporated in planning and building design approval.

${ }^{12}$ The CCTV specification was approved by the Council for Local Government (MNKT) in the first haft of 2007. This replaces the earlier CCTV guideline by the Local Government Department of 2004. The Federal Town and Country Planning Department and Local Government Department of the ministry are joint secretariat to the CCTV Task Force assigned to produce the CCTV specifications.

${ }^{13}$ The Research and Development Division of the Federal Town and Country Planning Department is the secretariat to the safe city programme.

${ }_{14}$ Sabah and Sarawak are not included in the reporting. The programme has been presented to the two states and they have showed interests in the measures. In particular the mayor of Kota Kinabalu is interested in joining the programme. 
Not to burden the PBTs at the initial stage, the Minister of MHLG had directed that 5 measures be implemented immediately:-

Table 2: Five Immediate Measures To be Implemented

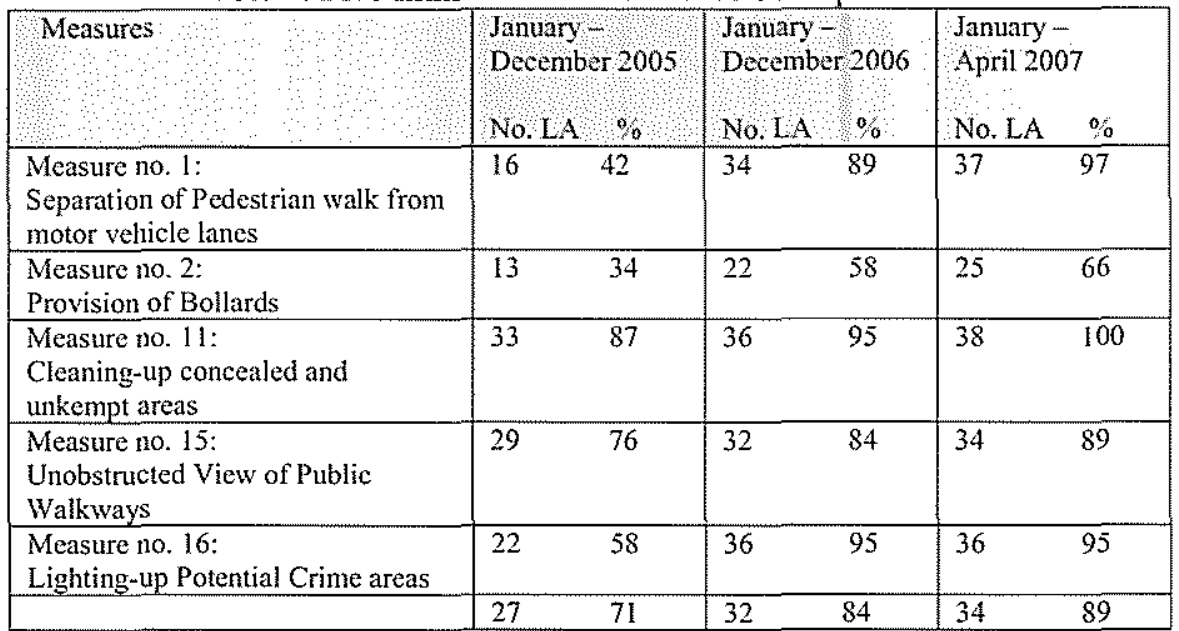

Source: Based on various PBT reporting. May - October 2007 reporting currently been undertaken.

It would appear by April 2007, only measures relating to cleaning-up unkempt areas have been fully implemented by all PBTs. However, there appeared some doubt based on reports of local visits by the secretariat and the media illustrating many crime prone areas still unkempt (for example, reporting by Star Metro dated 21 November 2006 for Kajang where residents didn't agree with the PBT that such measures were widely implemented). Admittedly, this could be true of other measures reported - the point is that their coverage was still small or insignificant compared to crime prone areas to make an impact.

\section{WHAT SAFE CITY MEASURES RECEIVED POOR RESPONSE?}

Based on the reports by the secretariat, the following measures received poor response (as of April 2007):-

Table 3: Least Implemented Safe City Measures

\begin{tabular}{lll}
\hline Measure no. 5 & Crime Mapping & only 7 PBTs implemented \\
Measure no. 9 & Safety Mirrors & only 17 PBTs implemented \\
Measure no. 10 & Alarms & only 10 PBTs implemented \\
\hline
\end{tabular}


The implementation of crime mapping is still at its infancy and seven PBTs having done this should be congratulated. Such mapping is very important for well coordinated crime-preventive measures between various agencies, more so for rehabilitating crime hotspots with adequate funding of social facilities etc. which could be secured from relevant ministries (for example Ministry of Women, Family and Community Development where their pusat rujukan social (social reference centre) may be funded by the Ministry) or their pusat giat tumpuan (focus crime prevention location)..$^{15}$ The sharing of crime data between local authorities and local residents have yet to pick up compared to the situation in Melbourne and Adelaide where crime mapping provides useful resource to channel resources for handling various diverse crime types. In this regard, PBT-local resident joint crime-preventive activities are largely nonexistent -only a few PBTs have initiated limited crime-preventive activities, but even these had no staying power and disappeared from the PBT calendar soon later. Melbourne had placed the month of October for promoting local initiatives on various safety issues (including crime prevention). It even had a mayor's city safety award to deserving local residents. Indeed, Melbourne's safety issue coverage and activities are very diverse and has been continually improving to cover diverse population age group and ethnicity ${ }^{16}$-. a coverage too incomprehensible for our PBT to visualize, much less initiate.

Safety mirrors were largely placed at road junctions and parking areas for the purpose of preventing accidents and (strangely) not for overcoming blind spots of street and alley corners; thus PBTs have still to understand the proper application of this measure despite various teach-in sessions undertaken by the secretariat. In Adelaide, such mirrors are placed slightly above pedestrian walkways allowing an eye-view of alleyways or side streets from potential crime purveyors.

Measures seeking the installation of alarms were largely neglected and we only see them in certain basement parking lots (which is very useful when thefts are about to happen and the victim requires immediate assistance from the hotel/complex security). In Melbourne, the city has undertaken safe city car parks accreditation scheme; and event introduced safe city taxi ranks to provide safety to passengers aided by the security staff making sure visitors reach home safely. Similarly, Adelaide too has such services. These two measures i.e. car parks accreditation scheme and taxi ranks could replace alarms in public areas.

15 Based on briefing session with the Ministry of Women, Family and Community Development in 2006 given by the author.

${ }^{16}$ City of Melbourne: Application for Re-designation to the World Health Organisation Safe Community Network. October 2006. See website www.melboume.vic.gov.au 
Perhaps a small pilot scheme could be tried in one of our cities, say Johor Bahru given its almost 24 hour business activity and people movement due to its close proximity to Singapore.

On-street alarms are nowhere implemented - only the police have recently placed a talk/camera system in Bukit Bintang on an experimental basis. However, the author has personally checked (pressed and talked) two of this talk/camera system at Sungei Wang and another at Maju Junction (both in Kuala Lumpur) only to find them not functioning ${ }^{17}$.

\section{LOCAL AUTHORITIES RESPONSE TO THE 23 MEASURES?}

By the fifth report (for January -April 2007), only Shah Alam reported having implemented $100 \%$ of the 23 measures. Eight other PBTs implemented $90 \%$ of the measures and above i.e., Johor Bahru, Petaling Jaya, Melaka Bersejarah, Kajang, Johor Bahru Tengah, Klang, Kulai, and Batu Pahat.

While the following seventeen PBTs implemented $70-90 \%$ of the measures i.e. Ipoh, Seremban, Alor Setar, Taiping, Subang, Kuala Kangsar, Kulim, Kluang, Kuantan, Teluk Intan, Alor Gajah, Ampang Jaya, Selayang, Temerloh, Sepang, Kota Bharu, and Sungai Petani. It would be interesting to discuss why Johor Bahru, Petaling Jaya, Ampang and Selayang continue to be hotbeds of crime occurrences despite favourable reporting. Their crime prone areas were widely distributed and measures were inadequate to cover them. Further motorcycle theft had pushed property crime index of PBTs making the PBT appear a crime ridden environment.

Thirteen PBTs performing below $70 \%$ but above $50 \%$ were Pulau Pinang, Manjung, Nilai, Pasir Gudang, Seberang Prai, Kluang, Muar, Kuala Terengganu, Bentong, Port Dickson, Kemaman, Langkawi and Kangar.

Thus, we could surmise that about $34 \%$ of the 38 PBTs were still far from full implementation of the 23 safe city measures; and the coverage of the 23 measures were limited compared to the total crime prone areas.

17 The system was checked on $17^{\text {th }}$ November at $4.10 \mathrm{pm}$ Sungai Wang and about $6.00 \mathrm{pm}$ at Maju Junction. A conversation with Dato Kamaruddin Ali (Exco member $\mathrm{MCPF}$ ) indicated that the system was provided by the private sector and during its experimentation period was manned by the police. Was the experimentation period over? 


\section{OF CCTV AND THEIR IMPACT?}

To-date only 12 PBTs have installed CCTV either through direct purchase or rental/leasing. The greater majority of PBTs have cited cost as a major constraining factor to their implementation ${ }^{18}$. Related issues to CCTV implementation includes:-

1. Many of the CCTV installation are not operated by the Police (resulting in poor response or no response);

2. Poor quality of image due to camera capture resolution (less than $470 \mathrm{~K}$ image pixels or 470 TV lines horizontal resolution) ${ }^{19}$;

3. Occurrence of disturbances from usage of unregulated band-width instead of conforming to the public safety standard band of $4.9 \mathrm{GHz}$;

4. High cost of maintenance;

5. Limited installation of CCTV locations;

On the whole, PBTs having installed CCTV have reported a significant drop in snatch theft, example Johor Bahru, but not in Petaling Jaya and Ampang Jaya. The following preliminary and inconclusive judgement could be made of CCTV installation (based on April 2007 reporting to the safe city secretariat) which indicated that:-

Major PBTs implementing CCTV in 2006 showed a declined in snatch thefts reported compared to 2005. PBTs include Johor Bahru Selatan (18 units, drop $30 \%$ ), Subang Jaya (100 units, drop 31\%), Shah Alam (17 units, drop 40\%), Manjung (39 units, drop 2\%), Melaka Tengah (21 units, drop 36\%). Penang showed a drop of $29 \%$ but no data on CCTV units were available, although it was reported in 2005 there were six units manned under the Safe City Initiatives (MCPF).

However a number of PBTs with CCTV continued to show increase in snatch theft compared to 2005. PBTs in this group are Johor Utara (18 units, increase $194 \%$ ), Petaling Jaya (22 units, increase 10\%), Ampang (48 units, increase $10 \%$ ), and Klang ( 6 units, increase $17 \%$ ).

\footnotetext{
${ }^{18}$ A sample of the cost range is: in Sg. Petani with 5 units, RM 131,000 while Petaling Jaya with 22 units RM 2.6 million. Rental-wise Klang RM 15,000 per month and Pulau Pinang RM 1.2million. Given this wide variation in cost it is hope the revised CCTV specification will provide much needed advise to the PBTs.

19 Program Bandar Selamat - Spesifikasi Teknikal Minimum Pemasangan Sistem CCTV DiKawasan Pihak Berkuasa Tempatan. (2007). Kementerian Perumahan dan Kerajaan Tempatan.
} 
PBTs with CCTV installed, and also a high level of steps implemented did show a positive drop in snatch theft reporting: examples are Johor Bahru with 22 steps with a drop of $30 \%$ snatch theft; and Melaka with 22 steps with a drop of $36 \%$.

A number of PBTs with a low level of steps implemented despite having installed CCTV showed no decrease in snatch theft occurrences: example Seberang Prai and Ampang Jaya.

A statistical correlation tested on 19 PBTs which showed a drop in snatch theft revealed a weak correlation of CCTV contribution to snatch theft reduction i.e. at about $27 \%$.

From the above preliminary assessment, it may be suggested that a combined CCTV and other safe city steps could have contributed to a decrease in snatch theft occurrences -but it is inconclusive. The above assessments do take into account data up to December 2007. The latest statistics showed snatched thefts have remained stable around 9500 cases per year at national level.

\section{SEEING THE BIGGER PICTURE AND IMPACT OF MEASURES TO CRIME REDUCTION}

\section{Global Comparison:}

According to PDRM (2006) Malaysia's crime rate of 589 per 100,000 is better than Hong Kong (1117), Brunei (959), Singapore (844), but higher than Indonesia (77). Malaysia also fares better than America (4617), Australia (6979), England and Wales (8545) and many other European countries (Schneider and Kitchen,2002); France (7002), Canada (8121), Korea (3494), Japan (1773) (sourced from PDRM, 2002). Thus Malaysia is considered a very safe country by such comparison. Such view is shared by Dr. Sundramoorthy, a criminologist from University Sains Malaysia (see The STAR 13 January 2008).

But countrywide data is meaningless to the individual. Statistics by cities would give a better picture. At this point in time I have not the opportunity to do this, and the most likelihood of this happening will be using data from various local plans and calculate their ratios with the police district (that's how the police

${ }^{20}$ Sample size 19 PBTs. Correlation value 0.23 ; Test value 2.11 and Critical value 2.10 . Total decline for 11 PBTs equals $786 \mathrm{cases}$; and total snatch theft showing decline in 2005 equals 2886 . Therefore contribution equal $27 \%$. 
delimit their crime statistics), although slightly showing an error of $10-15 \%$, they would be useful to compare between cities in Malaysia and those overseas.

\section{WHAT COULD WE SAY OF PROPERTY CRIME 2002-2007?}

Between the period 2002 till 2006, all categories of property crime reported increased in occurrence except for snatch thefts. Snatch thefts declined from 2003 towards 2006, and minimally increased in 2007 (additional 53 cases nationwide). The decline coincided with the implementation of the safe city program. At this point in time, it is not possible to ascertain such general decline and whether the safe city programme had contributed positively in this direction - I would like to think so, but the lack of extensive coverage and lack of concerted effort on the whole appear to negate this reasoning (and this bothers me). Further crime displacement to other neighbouring areas could not be discounted.

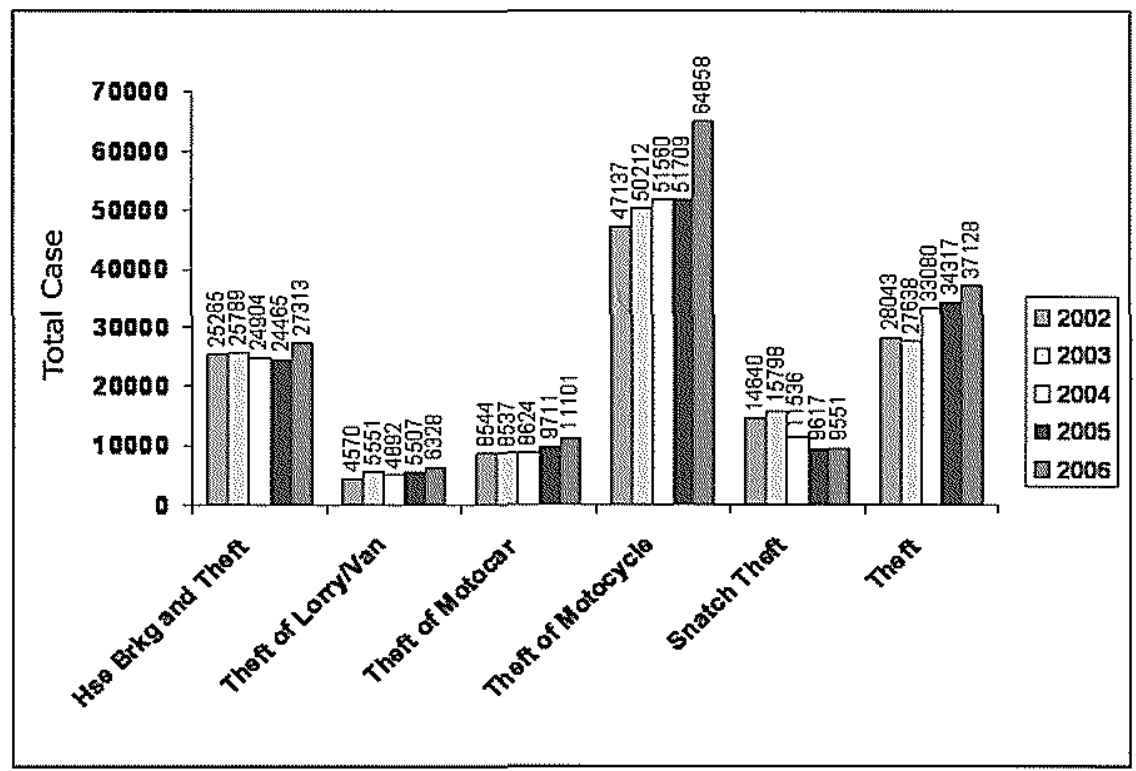

Figure 1: Property Crime at National Level (2002-2006)

21 Carmona, Heath, Oc and Tiesdell (2003) had classified different forms of displacement i.e. geographical displacement, temporal displacement, tactical displacement and crime type displacement, in their approach to Safety and Security of the The Social Dimension chapter (page 119-124). 
House break-ins (burglaries) showed no decline despite ten measures were targeted at this crime. PBTs which have managed to reduce house break-ins are Shah Alam and a small number of other PBTs (Taiping, Alor Star, Manjung etc). As shown in the figure 1.

Motorcycle thefts show unrelenting increase, and in 2006 they appear to increase further. Looking closely at the PBT level, only Malacca showed a decline in motorcycle theft. Has the innovative measures it introduced (motorcycle locking system) contributed to this? Probably the motorcycle locking system was more widely implemented in Malacca compared to other PBTs. It has been said on numerous occasions by the police, only when we are able to tackle motorcycle thefts successfully will the improvement in crime index be realized.

Indeed, visits to basement car parks and multi-story parking facilities clearly show lack of concern over crime prevention designs example walls and columns obstructing clear line of sight and entrapment spots. Newer complexes like Time Square have good parking design conforming to CPTED principles (i.e. clear sightlines, signages, lightings and materials) but many complexes from the 38 local authorities do not have such safety features.

Snatch thefts peaked in 2003, and thereafter declined beginning with 2004, 2005 and 2006. Was the decrease in snatch thefts a result of the safe city measures? The safe city programme had nineteen measures targeted at preventing snatch thefts. Assuming such measures did contribute, much more initiatives/implementation would be needed given the slower decline from 2005 to 2006 and a minimal increase in 2007.

\section{TOP TEN PBTs WITH HIGH PROPERTY CRIME}

Johor Bahru continues to be on top of the list, highest for four out of six property crime category in 2006. But it had certainly improved from the situation in 2005 when it topped five out of the six categories (i.e. with marked decline in snatch theft -544 cases). Maybe the CCTV was really effective here compared to other PBTs. Other PBTs occupying top ranking include Subang Jaya, Ampang Jaya, Pulau Pinang, etc. 
Table 4: Local Authorities Ranked according to Property Crime Severity (2006)

\begin{tabular}{|c|c|c|c|c|c|c|}
\hline $\begin{array}{l}\text { Housse Brooke } \\
\text { und then }\end{array}$ & Thell of & Thoted or & Thest of & Sratet thet & Thent & \\
\hline 0.6191593 & S & Pod 1453 & 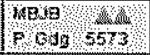 & 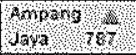 & $\mathrm{MBNB}, \mathrm{ON}, 1840$ & \\
\hline 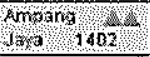 & $\begin{array}{ll}10 \mathrm{jB} \\
\mathrm{P} 0 \mathrm{~d}, 042\end{array}$ & \begin{tabular}{|ll} 
Petalingy & AA \\
Jaya & 311 \\
\end{tabular} & S. Peral $\begin{array}{r}\text { AhA } \\
3632\end{array}$ & \begin{tabular}{|l|r|} 
Pelaling & 4 \\
Jaya & 698 \\
\end{tabular} & \& & \\
\hline 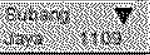 & $\begin{array}{l}\text { Petaling } \mathrm{AL} \\
\text { Jaya } \\
\end{array}$ & W & B & F & \begin{tabular}{|lr} 
Petaling & $\checkmark$ \\
Jaya & 1761 \\
\end{tabular} & \\
\hline $\begin{array}{l}\text { Petaling } \mathbb{A} \\
\text { Jaya to58 }\end{array}$ & $\begin{array}{c}\text { Selayang } A \Delta \\
413\end{array}$ & 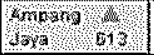 & $\begin{array}{ll}\text { Petaling } & \text { HA } \\
\text { Jaya } & 3372\end{array}$ & $\begin{array}{l}\text { Mena } \\
\text { P Od, }\end{array}$ & Anporng 1748 & \\
\hline${ }_{1006}^{\mathbb{A}}$ & $\begin{array}{ll}\text { Klang } & \underset{370}{\text { लA }} \\
& \end{array}$ & 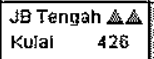 & (5) & 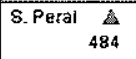 & Gelaka $\begin{array}{r}\Delta \mathrm{A} \\
1412\end{array}$ & \\
\hline$\underset{907}{\Delta \Delta}$ & 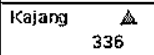 & $\underset{400}{\Delta}$ & $\begin{array}{r}\text { Shah Alam A A } \\
2254\end{array}$ & $\begin{array}{l}\nabla \nabla \\
398\end{array}$ & $\begin{array}{|lr|}\text { Ipoh } & \underset{1297}{\nabla V} \\
& 1297\end{array}$ & \\
\hline S. Perai $\begin{array}{r}\mathrm{A} A \mathrm{~A} \\
\\
\mathbf{8 3 5}\end{array}$ & Arroang & \begin{tabular}{|r} 
Selayang \\
\\
346 \\
\end{tabular} & Klang $\begin{array}{r}\text { A } A \\
1990\end{array}$ & $\begin{array}{r}\text { Selayang 命 } \\
274 \\
\end{array}$ & \begin{tabular}{|r|} 
Selayang 14 \\
1269 \\
\end{tabular} & $\begin{array}{l}\text { A Case increase } \\
\text { Case increase }\end{array}$ \\
\hline $\begin{array}{c}\text { Seremban } \nabla \\
774\end{array}$ & $\begin{array}{l}\text { Je Tengah } 4 \text { Kulai } 232 \\
\text { Kuil }\end{array}$ & Kajang $\underset{324}{\stackrel{\Delta}{A}}$ & $\begin{array}{c}\text { Selayang Ad血 } \\
1980\end{array}$ & Vrrox & S.Perai $\begin{array}{r}\mathrm{A} A \\
1217\end{array}$ & 80 case \\
\hline Kuantan $\underset{726}{\mathbb{A 4}}$ & $\begin{array}{r}\text { Shah Alam \& } \\
144\end{array}$ & ${ }_{259}^{\Delta}$ & \begin{tabular}{|l|} 
JE Tengah $A \Delta$ \\
Kutai 1965
\end{tabular} & belaka $\begin{array}{r}\nabla \\
\\
175\end{array}$ & 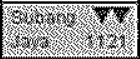 & $\begin{array}{l}\text { Case decrease } \\
\text { Case decrease }\end{array}$ \\
\hline Melaka & $\begin{array}{c}A \\
102\end{array}$ & 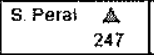 & Bmorar 1092 & $\begin{array}{r}\text { Seremban } \mathrm{A} \\
160 \\
\end{array}$ & $\begin{array}{r}\text { Shah Alamp } \\
1003\end{array}$ & $>100$ case \\
\hline
\end{tabular}

Source: Based On All IPK Negeri (PDRM), September 2006

This basically indicates that the above PBTs have to be given greater attention should the question of priority is considered. Given the concern over snatch thefts and property crime index overall, an additional classification had been suggested for classifying PBTs according to crime severity (particularly for CCTV installation and other concerted initiatives, and more importantly for funding purposes) ${ }^{22}$.

\section{RECENT IMPROVEMENT TO THE SAFE CITY PROGRAMMES}

a. The ministry had classified the 38 PBTs into three categories of crime severity i.e. (a) critical, (b) less critical, and (c) non-critical. Three criteria used in determining the classification of PBTs were (a) total property crime index (more than 5,000 cases per year for critical, 2000 $-4,999$ cases for less critical, and less than 2000 cases for non-critical PBTs), (b) snatch theft (more than 250 cases for critical, $100-249$ cases for less critical, and less than 100 cases for non-critical PBTs) and (c) whether PBTs were centres of international tourist attraction.

22 This classification had been endorsed by the National Council for Local Government in 2007 and currently been used to work out funding purposes for CCTV installation etc. for PBTs classified 'very critical'. Latest up-date: In January 2008, the Cabinet had approved a special funding of RM75 million for CCTV installation for the remaining Ninth Malaysia Plan. 
b. In January 2008 the MHLG through its Local Government Department made plans to tender out CCTV installation. This was based on the recent approved funding for the Ninth Malaysia Plan of about RM75 million. For the year 2008, a certain undisclosed amount was allocated.

c. PBTs classified critical includes Johor Bahru, Pasir Gudang, Petaling Jaya, Pulau Pinang, Subang Jaya, Ampang Jaya, Seberang Prai, Selayang, Johor Bahru Tengah, Kulai and Ipoh (see table next page).

d. PBTs classified less critical are Shah Alam, Seremban, Nilai, Klang, Melaka, Kuantan, Alor Star, Sungai Petani, Kuala Terengganu, Kota Bahru, Kajang and Muar (see table 5).

e. A revised CCTV installation guideline had been approved by the National Council for Local Government in 2007. It relates to system transmission, architecture and network infrastructure, system configuration and appliance specification; and maintenance checklist. PBTs in the critical category would have specification beyond what is provided in the CCTV installation guidelines.

f. PBTs should give greater concern on crime mapping with cooperation from the police and the public. This measure is considered very important in initiating PBT-police-public involvement in crime prevention activities. [more so if we are to benchmark against international standards where public involvement is vital for accreditation of a safe city status from WHO]

g. With respect to the above (vi) concern, safe city committee at PBT and State level should be operating on a regular basis compared to current one-off, irregular or non-existent situation. 
Table 5: PBTs according to Property Crime Severity Classification

\begin{tabular}{|c|c|c|c|}
\hline CATEGORY & CRITICAL & LESS CRITICAL & NON CRITICAL \\
\hline \multirow{2}{*}{ 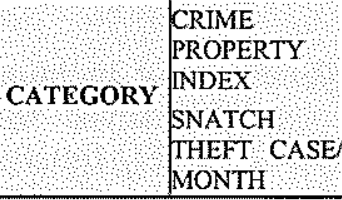 } & 5,000 case & $2,000-4999 \mathrm{case}$ & 2,000 case \\
\hline & -250 case & $100-249$ case & $100 \mathrm{case}$ \\
\hline \multirow{15}{*}{ Local Authority } & MB Johor Bharu? & MB Shah Alam & MP Batu Pahat \\
\hline & PBT Pasir Gudang & MP Seremban & MP Kulim \\
\hline & MP Petaling Jaya & MP Nilai & MP Taiping \\
\hline & MP Pulau Pinang & MP Klang ${ }^{t}$ & MP Sepang \\
\hline & MP Subang Jayat & MB Melakat & MP Alor Gajah \\
\hline & MP Ampang Jaya & MP Kuantant & MP Kluang \\
\hline & MP Seberang Perai & MB Alor Star & MP Teluk Intan \\
\hline & MP Selayang. & MP Sungai Petani & MP Manjung \\
\hline & MP J Baliru Tengalı & MPK Terengganü & MP Kemaman \\
\hline & MP Kulai & MP Kota Bharu? & MP Kangar \\
\hline & MAB Ipoh: & MP Kajang & MP Temerloh \\
\hline & & MP Muar & $\begin{array}{l}\text { MP Port } \\
\text { Dickson }\end{array}$ \\
\hline & & & MP Langkawit: \\
\hline & & & $\begin{array}{c}\text { MP Kuala } \\
\text { Kangsar }\end{array}$ \\
\hline & & & MP Bentong \\
\hline
\end{tabular}

Note: * denotes PBTS with international tourist presence.

\section{SOME IDEAS FROM MELBOURNE AND ADELAIDE}

(a) Lessons from Melbourne and Adelaide showed that the structure of local government and accountability of its elected mayors and councilors plays a major influence driving towards a safer city status. Both cities have a dedicated staff to handle crime prevention activities, in particular Melbourne's effort on various safe city fronts benefiting various age groups and ethnicity. Our PBTs despite with city status do not have a dedicated staff handling safe city task; this is even more so at municipality level where staffing is more acute and overburden with various municipality duties.

(b) The aspect on accreditation for a safe city status by WHO and accreditation for parking facilities of complexes both play a positive effect for the city effort and its attractiveness for international competitiveness and attractiveness of building premises (rating high for potential users etc. in 
regards safety) respectively. Our safe city programme probably can examine this potential avenue or direction.

(c) Both Cities have embedded CPTED into their planning and building approval process. Though the Malaysian Safe City programme has benefited from an early introduction to CPTED, some of CPTED features are already in the 23 measures. But to make this more effective CPTED features must be embedded in our planning approval process and building design approval stage too. Thus, CPTED would have to be targeted at the layout plan approval stage, and at the building design stage. To cater for both stages, CPTED guidelines for both will have to be prepared to suit Malaysian setting, although most features are universal.

(d) Perhaps the most important lessons that could be learnt from both cities is the partnership between the city and its police and citizen, and their various task forces and working groups continuously examining and improving safety measures largely based on what Colleen Lazenby (Manager Community Safety and Wellbeing, Melbourne City Council, 2007) called the evidence-based planning i.e. "the insistence on data to inform and drive agendas, delivering consistency and reliability in the representation of city safety by all stakeholder" ${ }^{23}$. Thereby promoting a bottom up process of safe city measures from the public, police and other stakeholders themselves, rather than from the top or from the Federal Government Ministry - when this happens, then safe city programme would likely have made a meaningful impact on crime reduction through wider ownership and action.

(e) As in all programmes, management dictates the need for some form of auditing or rather, how well the programme has gone. So, public survey or perception as to how the safety level has been perceived or crime reduced (or otherwise) needs to be conducted on a regular basis. These surveys, properly conducted, provide vital information not only on outcome, but also the ranking of sites or locations as to the rating of crimes or perceived risk level of crime by the public, thereby justifying prioritising such areas for improvement and funding requirements etc. (as are been conducted in Adelaide and Melbourne). Thus, the safe city programme in Malaysia should move in this direction and perhaps touch-base with the public for all the PBTs concerned - what and how do they perceive safety issues and what measures are more meaningful in bringing down crime occurrence can be pursued vigorously.

${ }^{23}$ City of Melbourne: Application for Re-designation to the World Health Organisation Safe Community Network. October 2006. See website www.melbourne.vic.gov.au 


\section{CONCLUSION}

It is hoped that this paper has provided some key aspects of the safe city programme under the Ministry of Housing and Local Government. Much remains to be done at the Ministry, state and local level for the programme to achieve a meaningful reduction in crime occurrence, a task of considerable magnitude given existing institutional structure constraint and current inertia towards empowering public decision and involvement in crime prevention.

\section{REFERENCES:}

Adelaide City Council. (undated). A Booklet on 'City Strategies: Community Safety Strategy (2003-2007)'.

Carmona, M., Heath, T., Oc, T., and Tiesdell, S., 2003. Public Places, Urban Spaces. The Dimension of Urban Design. Architectural Press. City of Melbourne: Application for Re-designation to the World Health Organisation Safe Community Network. October 2006. See website: www.melbourne.vic.gov.au

Kamalruddin Bin Shamsudin, 2007. "Safe City: Ministry of Housing and Local Government" in "A Safe City Is A Just City", World Habitat Day. Kuala Lumpur (22nd. November 2007) organised by MHLG, EAROPH and UN-HABITAT.

Kementerian Perumahan dan Kerajaan Tempatan, 2007. Program Bandar Selamat - Spesifikasi Teknikal Minimum Pemasangan Sistem CCTV DiKawasan Pihak Berkuasa Tempatan.

Kitchen, T., and Schneider, R.H., 2002. Planning for Crime Prevention A Transatlantic Perspective. Routlege: The RTPI Library Series

Lazenby, C., 2007. "Melbourne Safe City Initiative" in "A Safe City Is A Just City", World Habitat Day. Kuala Lumpur (22nd. November 2007) organised by MHLG, EAROPH and UN-HABITAT

Melbourne City Council. (undated). Safe City Car Parks Accreditation Scheme. 